\title{
Sheehan's Syndrome Presenting with Hypothermia and Hypoglycemia after Uterine Rupture during Labor
}

\author{
Kuan-Ying Huang ${ }^{1}$, Yi-Ping Li ${ }^{1}$, Tai-Chang Chen ${ }^{2}$ and Shin-Yu Lin ${ }^{1 *}$ \\ ${ }^{1}$ Department of Obstetrics and Gynecology, National Taiwan University Hospital, Taiwan \\ ${ }^{2}$ Department of Obstetrics and Gynecology, National Taiwan University Hospital Hsin-Chu Branch2, Taiwan
}

Submission: April 13, 2017; Published: May 8, 2017

*Corresponding author: : Shin-Yu Lin, Department of Obstetrics and Gynecology, National Taiwan, University Hospital and National Taiwan University College of Medicine, Tel: +886223123456x70919; Fax: +886223816566, Email: lin.shinyu@gmail.com

Keywords: Sheehan's syndrome; Postpartum hemorrhage; Hypothermia; Pituitary insufficiency; Hypopituitarism

\section{Background}

Sheehan's syndrome (SS) is a parturition-related pituitary disease resulting from severe postpartum hemorrhage and can present with varying degrees of pituitary insufficiency. However, Sheehan's syndrome though rare is still one of the commonest causes of hypopituitarism in developing countries. We present a case of hypovolemic shock due to uterine rupture found during labor who presented with hypothermia and hypoglycemia one week after delivery.

\section{Case Report}

This 39-year-old pregnant woman, gravid-2, para-1, was found rupture of membranes at 39+6 gestational weeks. Neither fetal anomaly nor maternal complication was found prenatally. She had a history of previous Caesarean section due to cephlopelvic disproportion at her first birth 3 years ago. Due to rapid labor progress, a vaginal birth after Caesarean section (VBAC) was performed under patient's request. During the delivery, the patient's consciousness became drowsy and the vital signs were unstable. The APGAR score of the fetus was 0 ( $1 \mathrm{~min})$ to $1(5 \mathrm{~min})$. Cardiologist and pediatrist were consulted immediately. The sonography revealed massive as cites. Uterine ruptured was highly suspected; therefore, the patient was sent to the operation room immediately. Laparotomy disclosed internal bleeding $1500 \mathrm{ml}$, an intact previous Cesarean section scar and a ruptured wound over uterine posterior wall with $10 \mathrm{~cm}$ in size (Figure 1). Postpartum hemorrhage was also found after operation with blood loss around $1000 \mathrm{ml}$. After rupture wound primary closure, massive blood transfusion, medication as oxytocin and transamin given, patient recovered gradually.

One week after delivery, she suffered from hypothermia episode with the lowest body temperature around 32 degree celsius (Figure 2). Hypoglycemia (50mg/dL) was also found. Lab data disclosed no evidence of infection and endocrine function was as below, cortisol 2.6ug/dL in the morning, $\mathrm{LH}<0.09 \mathrm{mIU} /$ $\mathrm{mL}, \quad \mathrm{FSH}<0.21 \mathrm{mIU} / \mathrm{ml}, \quad \mathrm{P} 4<0.20 \mathrm{ng} / \mathrm{mL}$ and $\mathrm{E} 2: \quad 29 \mathrm{pg} / \mathrm{mL}$. Adrenal insufficiency and hypogonadotropic hypogonadism were diagnosed. Hypothermia episode recovered within 24 hours without steroid given. However, patient started suffered from hot flash, cold sweating and easily fatigue and was treated with Predonine, Estromon and Provera. 6 months postpartumly, we followed her endocrine function after discontinuing all the treatment for 1 month and lab data revealed cortisol $3.9 \mathrm{ug} / \mathrm{dL}$ in the morning, LH: $2.47 \mathrm{mIU} / \mathrm{mL}, \mathrm{FSH}: 4.16 \mathrm{mIU} / \mathrm{mL}, \mathrm{P} 4:<0.20 \mathrm{ng} /$ $\mathrm{mL}$, and $\mathrm{E} 2<10 \mathrm{pg} / \mathrm{mL}$. She was still diagnosed with adrenal insufficiency and hypogonadotropic hypogonadism. Brain MRI arranged 6 months after delivery also showed empty stella (Figure 3), which was compatible with the diagnosis of Sheehan's syndrome.

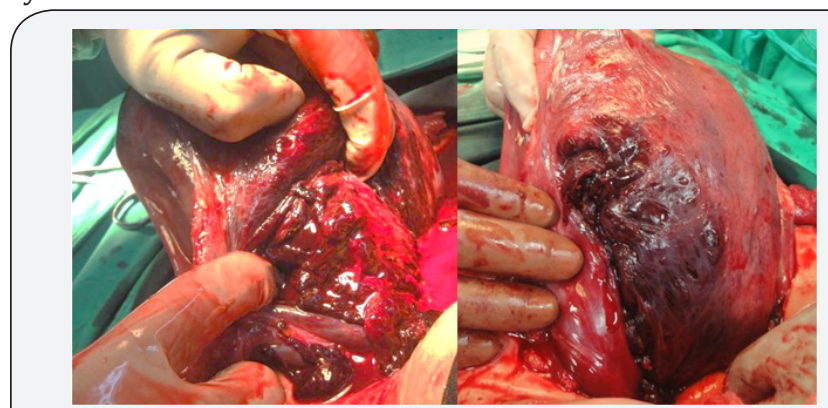

Figure1: Emergency laparotomy findings

(a) Posterior uterine wall rupture with $10 \mathrm{~cm}$ in size (b) Status post primary closure

Hypothermia episode with the lowest body temperature around 32 degree celsius was found one week after delivery and patient recovered spontaneously without steroid given within 24 hours. 

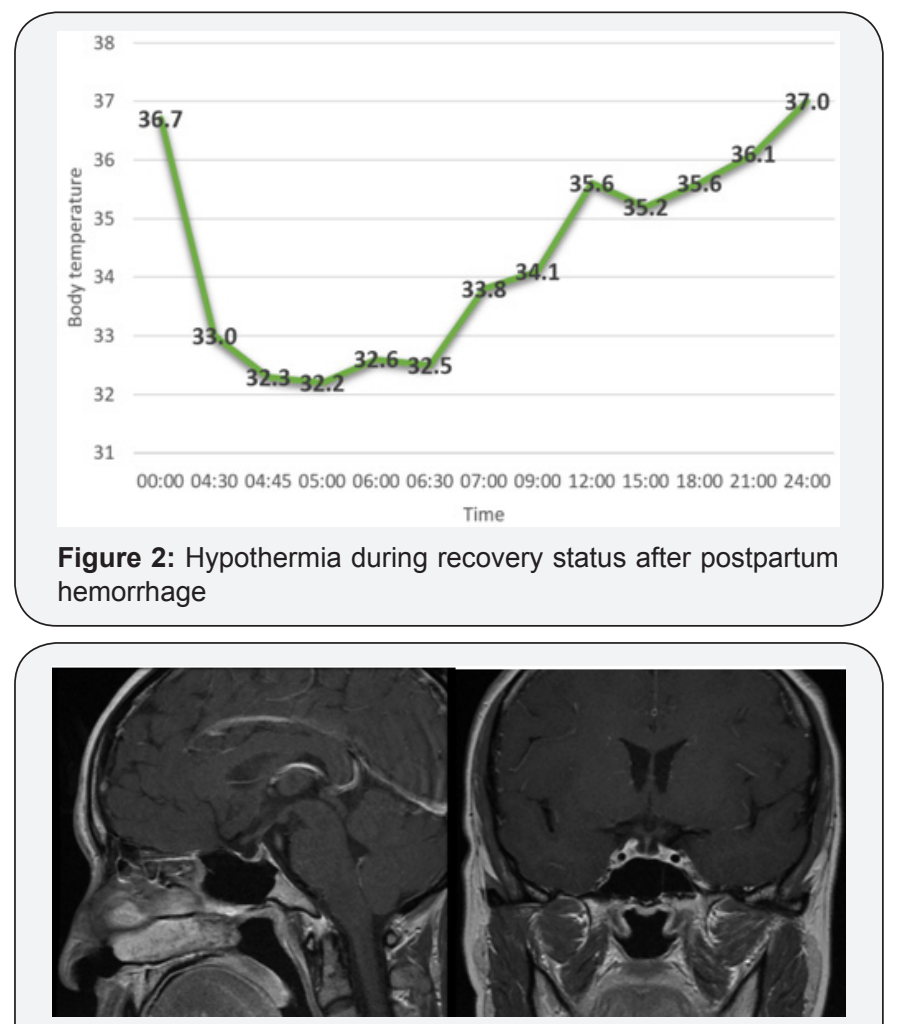

Figure 3: Brain MRI 6 months postpartumly: Empty stella.

(a) Sagittal view (b) Coronal view.

\section{Discussion}

Sheehan's syndrome is characterized by varying degrees of anterior pituitary dysfunction due to ischemic necrosis of pituitary gland after massive postpartum hemorrhage. It was first described by Sheehan in 1937 [1]. The diagnosis can be made reliably in the presence of lactation failure, prolonged amenorrhoea and hypoglycemic crisis. However, other signs of pituitary insufficiency are often delayed and subtle leading to diagnosis being missed. Seldom does the postpartum hypothermia be reported. Only one study stated a case of post-partum hypoglycemia and hypothermia happened due to lymphocytic adenohypophysitis [2]. Our study is the first case with Sheehan's syndrome in the presence of hypothermia.

The mean duration between postpartum bleeding and subsequent development of symptoms varies between 1 to 33 years. The diagnosis of Sheehan syndrome is based on the combination of pituitary-related hormone assay and MR imaging findings. The features of hormone deficiency include decreased levels of basal hormones (free T3, T4, TSH, FSH, LH, estrogen, prolactin, cortisol, and insulin like growth factor). MR imaging findings, within several weeks to months, show that the pituitary gland will have severe atrophy, leading to the appearance of an empty sella [3]. Treatment involves lifelong hormone replacement therapy and it is essential to replace the hormones that the pituitary gland fails to produce.

\section{Conclusion}

Sheehan's syndrome is a known complication, even if postpartum hemorrhage has been well managed, this complication cannot be excluded. It is necessary to consider this diagnosis in all patients having presented with cardiovascular collapse during childbirth, whatever the cause and in the presence of classical signs of pituitary insufficiency. We provided an extremely rare experience that hypothermia could be an initial presentation of the Sheehan's syndrome.

\section{Acknowledgement}

This work was supported by grants from the National Taiwan University Hospital (104-N2838 106-003682).

\section{References}

1. Diri H, Karaca Z, Tanriverdi F, Unluhizarci K, Kelestimur F (2016) Sheehan's syndrome: new insights into an old disease. Endocrine 51(1): 22-31.

2. Koyama S, Okuno K, Naoi H, Shiki Y (2016) Post-partum hypoglycemia and hypothermia as first manifestations of lymphocytic adenohypophysitis: A case report. J Obstet Gynaecol Res 42(4): 467470.

3. Kanekar S, Bennett S (2016) Imaging of Neurologic Conditions in Pregnant Patients. Radiographics 36(7): 2102-2122.
Your next submission with Juniper Publishers will reach you the below assets

- Quality Editorial service

- Swift Peer Review

- Reprints availability

- E-prints Service

- Manuscript Podcast for convenient understanding

- Global attainment for your research

- Manuscript accessibility in different formats

( Pdf, E-pub, Full Text, Audio)

- Unceasing customer service

Track the below URL for one-step submission https://juniperpublishers.com/online-submission.php 